\title{
自然観察園の設計と管理 一湿原の生態園における園路を中心に一
}

Design and Management of Nature Observation Park: Wetland Park's Footpath and other Facilities 高橋 勉*

Tsutomu TAKAHASHI

\section{はじめに}

今回，箱根湿生花園の建設過程を通して，人に見せるた めに，湿原の生態園をどのようなコンセプトで基本設計が 組まれ，どのような目的意識をもって施工をしてきたかを 紹介しながら，建設後 22 年たった湿生花園の管理の現状 と今後について論じてみたい。

箱根湿生花園は, 神奈川県では唯一の湿原「仙石原湿原」 の一角にあり, 湿生花園から直線距離でわずか 500 メート ルのところには, 昭和 9 年に国の天然記念物に指定された 「仙石原湿原植物群落」あある。箱根湿生花園は, この仙 石原湿原の保護之育成を兼ね, 仙不原湿原の一角で長い間 利用されず，放置されていた水田跡地に約 3 ヶ年の工事期 間を経て, 1976 年 5 月, 日本で初めての「湿原の植物園」 として開園した。

\section{1. 園の構成}

(1)当初計画から，仙石原湿原の見本園としての役割もあ り園全体の基本的な構成を生態園とした。

(2)仙石原湿原の保護と育成という基本方針から，仙石原

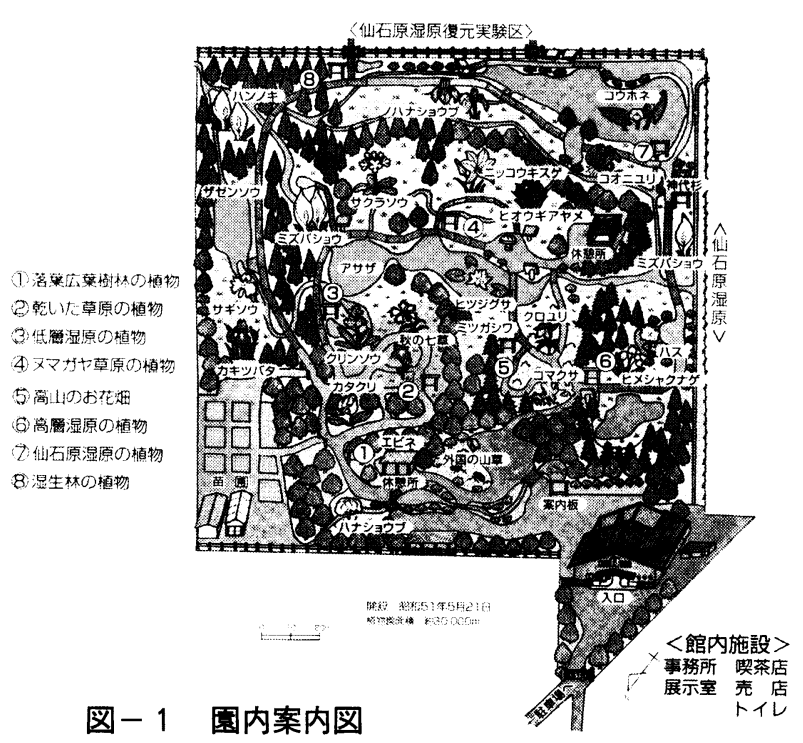

湿原の植物を中心に, 群落単位で低地から高山へ, 初期の 湿原から発達した湿原へと順に回れるように, 各植物群落 を配置した。

(3)植物園のエリアを生態園とそれ以外に区別する意味で 落葉広葉樹林と針葉樹林を設け生態園側を園内とし, 一方 をサービスヤード（多目的広場）と位置づけた。

(4)その他, 付帯設備として管理棟・展示室・苗圃・駐車 場を設けた。

\section{2. 基本設計の概要}

人工的に作られた環境が，人為的に管理されながらも極 力自然の植生景観に見えるようにする事を基調に，見せる 生態園とするため次のようなテーマに沿って計画を進めた。 (1)開園期間中，園内のよ゙こかに花が咲いているようにする。 (2)仙石原湿原の植物だけでは 7 月からのわずか数ヶ月しか 見せることができないので, 他の湿原群落を取り入れて 7 ヶ月以上開園できるようにする。(3)園の面積が 3 万 $\mathrm{m}^{2}$ と狭 い上ほとんど真四角の敷地であるため直線的な園路は最小 限にする。(4)地下水位が高いの之植物および植物保護のた め園路の主要部分は木道とする。(5)園内は, 原則として日 本の野生植物だけとする。

しかし，湿原群落だけでは単なる湿原のモデル展示になっ てしまうことから，周りも含め自然のように見せるため落 葉広葉樹林や常緑針葉樹林, 湿生林, ススキ草原, 高山の お花畑など湿原を取り巻く様々な群落も盛り込んだ。

\section{3. 園路の設置}

一辺約 170 メートルのほぼ真四角の敷地で遮る物がなけ れば誰が歩いているのか判るくらい狭い園内に，日本の湿 原の代表的なタイプの低層湿原, 中間湿原 (ヌマガヤ草原), 高層湿原までと, 仙石原湿原, 湿生林などのほか, 乾いた 草原, 高山のお花畑, 落葉広葉樹林などの群落をコンパク トに，しかも生態学的に根拠のある効果的な配置をしなけ ればならないことを考慮して, 一方通行の大きな逆 S 字園

*箱根湿生花園 
路を設置した。また各群落と群落が近いため，これを明確 に区別しないとただの草原にしか見えない。一般の人が見 たとき群落として判別がしにくい。視覚的に違いを強調す る意味で群落を取り囲む遮蔽林（向こうが少し見えるくら いの）を設けた。併せて園路を蛇行させることで見通しを 悪くし, 次の群落がどのようになっているのかなど期待と 想像を高めるように，園路の設定を行った。

\section{4.土道と木道}

(1) 土道

園路の構造的な分け方をすると, 土道と木道に分けられ 土道の良さについては(1)自然の雾囲気を出せる, (2)アスファ ルトに比べ植物に影響が少ない，(3)歩きやすくて疲れない, などの特徴がある。

構造的には, 土道の仕上がり厚を $300 \mathrm{~mm}$ として $270 \mathrm{~mm}$ 厚 の砕石（クラッシャーラン）材の上に, 単粒度砕石 7 号に 砕石ダストを混合した仕上げ材を $30 \mathrm{~mm}$ 厚敷き, 敷き均し 後転圧仕上げをした。

敷設後はできるだけ自然に近い形に見えるように管理し 雨天の時は, 一時的な排水路となる場合もある。入園者に 多少迷惑をかけることも承知の上で砕石路盤の土道にして きた。定期的に路盤の掘り起こしと敷設替えを行い，浸透 性の良い路盤を保たなければならない。アスファルトより こまめな管理が必要だが，自然らしさを基調にしているこ とからも $2 \mathrm{~m}$ 位の狭い園路は, アスファルトやコンクリー 卜道でないほうがよいと考えている。

また，開園後判ったことだが，アスファルト舗装を行わ ない万が好ましい理由のもう一つに，仙石原の冬期の気象 がある。雪があまり降らずに寒さだけは厳しく, 開園当初

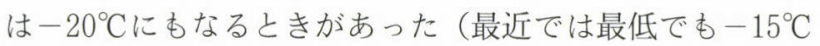
前後)。この低温と地下水位が $50 \mathrm{~cm}$ 之高いため, 土道表面 が $15 \mathrm{~cm}$ くい凍土となり霜柱が表面を盛り上げる。日中 は, 気温が高くなり表面が溶け翌日凍る。この繰り返しが 厳寒期の 2 月中続くとアスファルトに限らず敷設路盤は,

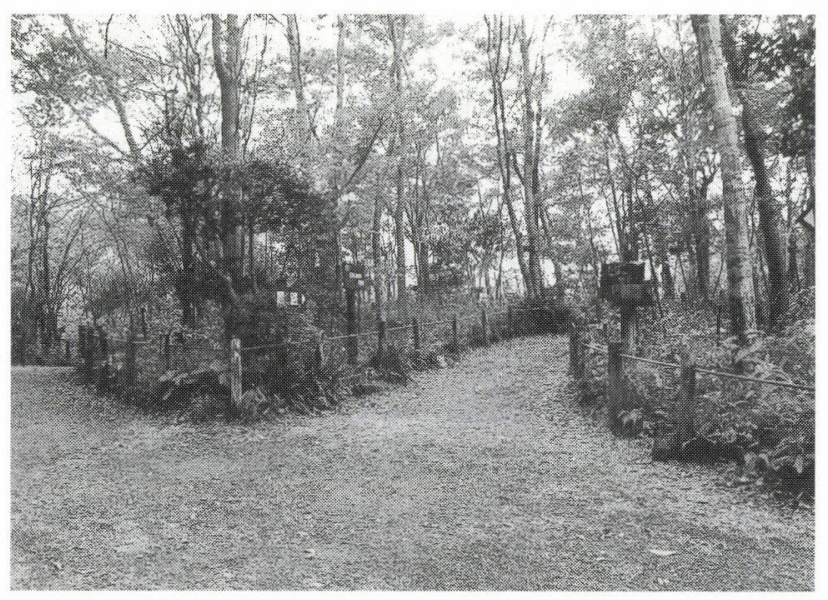

写真一 1 落葉広葉樹林入り口の土道
数年ででこぼこになって打ち返しを常に行わなければなら なくなる。 $50 \mathrm{~cm}$ な下のころに暗渠を設ければ凍土を防げ るが，暗渠は表面水位の影響を大きく左右し，湿生植物の 生育や園路維持費用の面からあ, 現在の土道形式が適して いると考えている。

土道の縁切りには既製品を使わず，自然石で縁止めをし 固定用のコンクリート類は一切使用しない方法を採った。 これはコンクリートから受ける人工的イメージを避けるこ とと, 酸性・貧栄養の土袞で湿地植物は生育していること から影響は少ないだろうが，大量に使用した場合にはコン クリートからのアルカリ分の流出が考えられるので, 自然 石を使用することとした。

さらに計画段階では, 園路 (土道) からそれて植物群落 の中に人が入ることなどほとんど考えなかっため, 開園後, 人止め柵を設ける必要がでてきた。この材料としては，水 に強い桧の丸太を違和感を感じさせないように，皮を剥き 腐朽防止をかねて表面を焼き，磨き上げた丸太にロープを 通して人止め柵とした。杭の高さは, ロープ位置がくぐり にくく，跨ぎにくい高さの地面から $550 \mathrm{~mm}$ と， これを標 準として，周囲の状況に合わせ多少の調節をし設置した。 丸太はすべて人力打ち込みとし, 杭丸太を固定するのにコ ンクリートは使用しないですむような深さまで打ち込みを して固定し，植生への影響を最小限にとどめるよう配慮し た。

\section{(2) 木道}

湿生花園を象徴するむのの一つに，園内に配した池や草 原を巡る木道がある。材質はすべて米松（主な樹種はアメ リカトガサワラ）を使用し，植物への影響を考え防腐剂は 使用しないで杭と桁の太さを $150 \mathrm{~mm}$ 角とし, 敷き板は, 同 じく米松の厚み $100 \mathrm{~mm} \times$ 幅 $160 \mathrm{~mm} \times$ 長さ $4,000 \mathrm{~mm}$ の平角材を 10 枚敷き並べた状態で 1 スパンとした。本来なら, 尾瀬 ヶ原のようにグランドレベルで設置をしたかったのだが，

(1)低いと群落の中に容易に入り込めてしまう，(2)それを防 ぐため人が入り込めないよう手すりや柵を全体に設けなけ ればならない, (3)柵を設置することで遠近感がなくなり園 の狭さが判ってしまう，(4)柵があることで自然らしさが失 われてしまう，(5)雨などで増水したときに歩けなくなって しまう, などから尾瀬ヶ原夕イプは止め, 湿生花園独自の 鳥居型の桁組をした上に平角材を敷き並べた構造にし，高 さはグランドレベルから500〜600 mmを仕上がり高とした。

(3) 木道の施工

軟弱地盤と植物保護から重機を使用することが出来ない ため, 杭の打ち込みはすべて人力施工となった。打ち込み には通常力ケヤを使用するが，杭が太いため普通の重さの ものでは跳ね返ってしまうので, 人力突き堅めに使う「夕 コ」を逆さに使用して打ち込んだ。

杭が四角であるため障害物に当たるとねじれたり向きが 
ずれたりする。これを防ぐために，杭に棒を向かい合わせ に取り付け棒を押さえることで，ねじれや傾きを調整した。

鳥居型をした土台の杭と杭の幅は, 敷き板幅とほぼ同じ かそれよりも狭くした。これは, 荷重の均衡を保つことと, 見た目のきれいさから最良の位置を決めた。角材の杭は, 丸太に比べ入手がしやすく，施工するにあ桁材を同じ寸法 にしたことで, 角度や平行, 左右のバランスを取るのが楽 であった。

主柱と主柱の間隔をほぼ 4 メトルとし, 中間に $90 \mathrm{~mm}$ 角の間柱を設置, 桁は木道の幅から出ないようにした。

敷板の厚みと幅は，規格にはない幅と厚みである。少な い本数で最大幅員を得るために，少し割高だが特注の 160 $\mathrm{mm} \times 100 \mathrm{~mm}$ の幅と厚みにした。板と板の隙間を $12 \mathrm{~mm}$ 前後に 押さえたことで, 車椅子やべビーカーのタイヤがはさまら

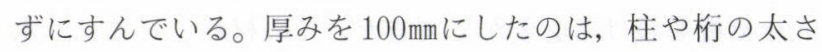
とのバランスや， $50 \mathrm{~mm}$ で歩いたときしなって間柱を多く しなければならないの之安定感や耐久性に不安を感じ, 75 mmでは耐久性は認められるが厚みがなく安定感に欠けるな どの理由による。

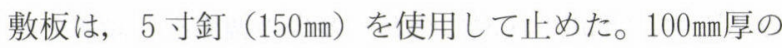
米松に対して $50 \mathrm{~mm}$ しか桁にかかっていないが, 既製品の 中では最あ長い釗である。あまり深く桁にかかっていると 釘穴からの腐朽も早く起きるので, この長さは程々に止まっ ていて十分である。

\section{(4) 施工後の維持管理}

木道を設置して 7 年もすると, 所々敷板に傷みが見られ るようになる。使用する材木の材質が心材部であったり辺 材部材であったりで，傷み方は一様ではないが多くは釷穴 と小口からの染み込んだ水が桁のところで密着しているた めに乾燥しにくく, 隙間の部分に落ち葉などが溜まって腐 朽しやすい環境を作り一番早く傷む場所である。溜まった 落ち葉を定期的に取り除くなどの管理が長持ちをさせる。 また，最近では違和感を感じさせない再生プラスチック製 の柱材やパイプで補強した桁材もある。敷板だけを交換す

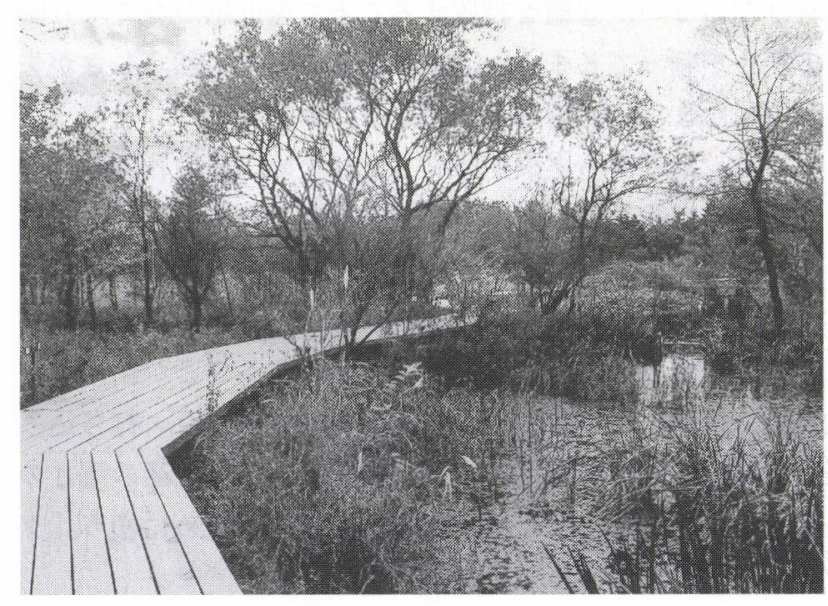

写真一2 園内の木道
れば木材などより数倍も長く使用でき，目的と用途が合え ば，十分使用に耐えるものである。湿生花園では 10 年に 一度駆体全部を交換してきたが, 交換工事時に安定し始め た木道周辺の植生を一時的に擋乱するなど弊害も大きいの で，工事による被害を最小限にすることと，長期的には資 源保護にもなることから, 現在では殆どの木道の駆体が再 生プラスチックに交換されている。

(5) 土道と木道の効果

今の時代どこへ行ってもアスファルトとコンクリートの 道ばかりで，土の道を歩くなどと言うことは，ほとんどな くなってしまっている。都市にある植物園ほどそうである ように, 我々を取り巻いている現代社会で[道]は, アスファ ルトが当たり前で，時たま地方へ行ったときに触れること の出来る「土の道」が妙に心地よく感じたことが誰しああ

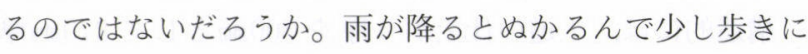
くいが, 自然の山道では当たり前のことである。また，木 道を歩くときの鞉音の響きや肌に触れたときの木のぬくも りを暖かいと, 誰しも感じるのではないだろうか。そのよ うな自然の持つ感触が土道や木道にはある。

また, 細長いスノコ状の木道を設置したことの大きな特 徵は, 横板で組んだ物より, 遠近感がでやすいということ である。折れ曲がりながら続く園路が両側の木々の間から 見えると，さらに強調されて狭い園内が広く見える効果が ある。

\section{5. 現状と今後の課題}

建設後 22 年を経過しょうとしているが，当初ほとんど が蔁原であったところが今こうして見回すと，手前味増で はあるが, 自然そのもののように感じる。人工の生態園と いうことで出発し, 紆余曲折しながらやってきたが, 植物 は生き物で日々变化する。手を入れなければあっという間 に強いものが優先してしまう。園内全ての植物を適正な量 と豊富な種類で，あたかも自然であるがごとく見せていく のが，生態園としての役割である。

自然園を施工・管理する者に求められるものは, 園路や 建物, ベンチに至るまで人工物をどれだけ自然と調和させ るか，見る者をどれだけ自然の中に迷い込んだと錯覚させ られるかであり，それが人を引きつける大きな要素となる のではないだろうか。生態園は植物園の分野ではまだ少な く, 管理できる人材も不足しているのが現状である。公園 や庭園を管理するのとは異なり, 林や草原がどのような種 類で, どのような自然環境で成り立っているのかなど, 発 生から現状に至るまでの過程を掌握していって初めて, 目 的に叶った生態園の管理に取りかかることができる。

生態園の管理は, 造園技術と植物の自然の生業を掌握し た生態学とが相まってできるあのと考える。今望まれてい るのはいわゆる文武両道の人材である。 